\title{
Synthesis, spectral, 3D molecular modeling and antibacterial studies of dibutyltin (IV) Schiff base complexes derived from substituted isatin and amino acids
}

\author{
Har Lal Singh*, Jangbhadur Singh \\ Department of Chemistry, Faculty of Engineering \& Technology, Mody Institute of Technology and Science, Sikar, India; \\ *Corresponding Author: hlsingh9@,rediffmail.com, hlsingh9@,gmail.com
}

Received 20 January 2012; revised 23 February 2012; accepted 5 March 2012

\begin{abstract}
New dibutyltin (IV) complexes of Schiff base derived from 5-chloroindoline-2,3-dione, indoline2,3-dione with amino acids (tryptophan, alanine and valine) were synthesized and characterized by elemental analysis, IR, electronic spectra, conductance measurements, and biological activity. The analytical data showed that the Schiff base ligand acts as bidentate towards metal ions via the azomethine nitrogen and carboxylate oxygen by a stoichiometric reaction of $M: L$ (1:2) to form metal complexes. NMR $\left({ }^{1} \mathrm{H},{ }^{13} \mathrm{C}\right.$ and $\left.{ }^{119} \mathrm{Sn}\right)$ spectral data of the ligands and metal complex agree with proposed structures. The conductivity values between $14-27 \mathrm{ohm}{ }^{-1} \cdot \mathrm{cm}^{2} \cdot \mathrm{mol}^{-1}$ in DMF imply the presence of non-electrolyte species. 3D molecular modeling and analysis of bond lengths and bond angles have also been conducted for $a$ representative compound, $\left[\mathrm{Bu}_{2} \mathrm{Sn}\left(\mathrm{L}^{2}\right)_{2}\right]$, to substantiate the proposed structures. Antibacterial results indicate that the metal complexes are more active than the free ligands.
\end{abstract}

Keywords: Schiff Base; Isatins; Amino Acids; Dibutyltin (IV) Complexes; Spectral Studies; Antimicrobial Activity

\section{INTRODUCTION}

Isatin, possessing an indole nucleus having both the keto and lactam moiety has aroused tremendous curiosity due to its diverse biological and pharmacological studies. From literature survey it is well known that isatin heterocycles exhibit manifold importance in the field of medicinal chemistry as a potent chemotherapeutic agent. Schiff base complexes have been extensively investi- gated for more than a century and employed in areas that include pharmaceutical, medicinal and coordination chemistry [1-7]. Schiff bases are potentially biologically active compounds and have been reported to possess antibacterial, antifungal, antitumor and anticancer activities [8-12]. Schiff bases have also been employed as ligands for complexation of metal ions [13]. On the industrial scale, they have wide range of applications such as dyes and pigments [14]. Schiff base metal complexes are more biologically active than uncoordinated Schiff base molecules [15]. Amino acid Schiff bases are an important class of ligands because such ligands and their metal complexes have a variety of application including biological, clinical, analytical and industrial in addition to their important role in catalysis and organic synthesis. It is well known that organotin (IV) complexes exhibit high biological activity such as antitumor and antimicro- bial activity [16-20]. The interest in organotin compounds in general and organotin carboxylates in particular continues to grow because of their biological activity and potential antineoplastic, antituberculosis agents [21,22]. Among those compounds dibutyltin derivatives have displayed both higher activity and lower toxicity [23]. Organotin complexes derived from carboxylic acids are among the most extensively studied class of compounds owing to their rich structural chemistry. The diverse structural motifs known in this family of compounds are attributed to the ambidentate character of the carboxylate ligands [24]. Steric and electronic attributes of organic substituents on tin and/or the carboxylate moiety impart significant influence on the structural characteristics in tin carboxylates. Therefore, synthesis of new organotin carboxylates with different structural features will be beneficial in the development of pharmaceutical organotin and in other properties and application.

Keeping in view the structural and biological diversity of organotin carboxylates and in connection with our 
interest in coordination chemistry of organotin compounds with different amino acids, herein we report the synthesis, characterization and biological studies of organotintin (IV) derivatives with Schiff base to widen their scope in biological applications. The structures of the ligands are shown in Figure 1.

\section{EXPERIMENTAL AND METHODS}

\subsection{Chemicals and General Methods}

All chemicals and organotin precursors used were procured from Aldrich and Merck. All the solvents were dried before use by the literature methods [25] and moisture was excluded from the glass apparatus using $\mathrm{CaCl}_{2}$ drying tubes. The melting points were determined in an open glass capillary and were uncorrected.

\subsection{Analytical Methods and Spectral Measurements}

Tin was estimated gravimetrically as $\mathrm{SnO}_{2}$. Nitrogen was estimated by Kjeldahl's methods. Molar conductance measurements were made in anhydrous dimethylformamide at $25^{\circ} \mathrm{C} \pm 5^{\circ} \mathrm{C}$ using a Systronics conductivity bride model 305. Molecular weight determinations were carried out by the Rast camphor method.

The electronic spectra were recorded in DMSO on a Thermo UV1 spectrophotometer. Infrared spectra were recorded on a Perkin-Elmer RX1 FTIR spectrometer in the region $4000-400 \mathrm{~cm}^{-1}$. ${ }^{1} \mathrm{H}$ and ${ }^{13} \mathrm{C}$ NMR spectra were recorded on BRUKER AVANCE II (400 MHz) FTNMR spectrometer at the SAIF, Punjab University, Chandigarh, using DMSO- $\mathrm{d}_{6}$ as the solvent and tetramethylsilane (TMS) as an internal standard. The ${ }^{119} \mathrm{Sn}$ NMR spectra with proton noise decoupling were recorded on a BRUKER Avance II spectrometer using dry DMSO as the solvent and tetramethyltin (TMT) as an external

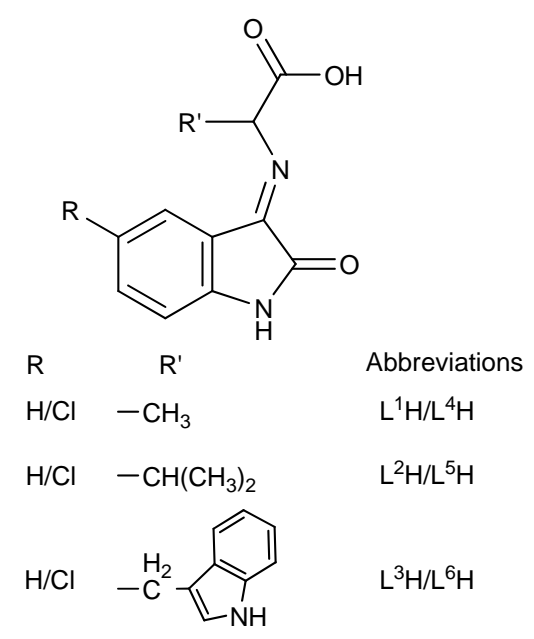

Figure 1. Proposed structure of the ligands. standard. The 3D molecular modeling of a representative compound was carried out on a CS Chem. 3D Ultra Molecular Modeling and analysis program.

\subsection{Syntheses of Schiff Base Ligands}

The ligands were synthesized by the condensation of indoline-2,3-dione (0.231 g; 1.57 mmole), 5-chloroindoline-2,3-dione (0.285 g; 1.57 mmole) with amino acids (0.140 - $0.321 \mathrm{~g} ; 1.57$ mmole) (tryptophan, alanine and valine $)$ in 1:1 molar ratio using methanol $(100 \mathrm{~mL})$ as the reaction medium and were then, it was refluxed for $6-8$ hours. After this it was put on cooling at room temperature and the solid products were obtained. The excess solvent was removed on a rotary evaporator. It was dried further and then purified by recrystallization from same solvent (Table 1).

\subsection{Syntheses of Organotin (IV) Complexes}

Dibutyltin (IV) oxide (0.280 g; $1.125 \mathrm{mmole})$ was added to the calculated amount of the ligands (0.491 $0.829 \mathrm{~g} ; 2.250 \mathrm{mmole})$ in 1:2 molar ratio in dry benzene $(80 \mathrm{~mL})$, methanol $(25 \mathrm{~mL})$ mixture as reaction medium. The contents were refluxed on a fractionating column for about $6-8$ hours. The water librated in the reaction was removed azeotropically with benzene. On completion of the reaction, the resulting products were rendered free from solvent and then washed repeatedly with dry cyclohexane. The crystalline solids were separated out and purified by recrystallization from the same solvent. The products so formed were finally dried in vacuum at $40^{\circ} \mathrm{C}$ $\pm 5^{\circ} \mathrm{C}$ for $2-3$ hours. The purity of the complexes was checked by TLC using silica gel-G as adsorbent. Their physical properties and analytical data were recorded in Table 2.

\subsection{Antibacterial Assay}

Synthesized compounds were screened for their antibacterial activity against Bacillus cereus (MTCC 0430) and Enterobacter aerogenes (MTCC 2824) at various concentrations 25,50 and $100 \mu \mathrm{g}$ by the agar Well Diffusion method [26]. $5 \mathrm{ml}$ aliquot of nutrient broth was inoculated with the test organisms and incubated at $37^{\circ} \mathrm{C}$ for 24 hours. Sterile nutrient agar plates were also prepared and holes of $5 \mathrm{~mm}$ diameter were cut using a sterile cork borer ensuring proper distribution. The test organisms after 24 hours of incubation were spread onto separate agar plates. The chemical compounds were dissolved in DMSO were poured into appropriately labeled holes using a pipette in aseptic conditions. A hole containing DMSO served as a control. Triplicate plate of each bacterial strain was prepared. The plates were incubated aerobically at $37^{\circ} \mathrm{C}$ for $24 \mathrm{~h}$. The antimicrobial 
Table 1. Analytical and physical data of the ligands.

\begin{tabular}{|c|c|c|c|c|c|c|c|}
\hline \multirow{2}{*}{ Ligands } & \multirow{2}{*}{ Colour } & \multirow{2}{*}{ Yield (g) } & \multirow{2}{*}{ M.P. ${ }^{\circ} \mathrm{C}(\mathrm{d})$} & \multicolumn{3}{|c|}{ Elemental Analysis } & \multirow{2}{*}{$\begin{array}{c}\text { Mol. Wt. } \\
\text { Found (Calcd.) }\end{array}$} \\
\hline & & & & $\% \mathrm{C}$ & $\% \mathrm{H}$ & $\% \mathrm{~N}$ & \\
\hline $\begin{array}{l}\text { 2-(2-oxoindolin-3-ylideneamino)propanoic acid } \\
\left(\mathrm{C}_{11} \mathrm{H}_{10} \mathrm{~N}_{2} \mathrm{O}_{3}\right) \mathrm{L}^{1} \mathrm{H}\end{array}$ & Pink & $\begin{array}{l}0.292 \mathrm{gm} \\
85.26 \%\end{array}$ & $106-107$ & $\begin{array}{c}60.64 \\
(60.55)\end{array}$ & $\begin{array}{c}4.56 \\
(4.62)\end{array}$ & $\begin{array}{c}12.89 \\
(12.84)\end{array}$ & $\begin{array}{c}228.71 \\
(218.21)\end{array}$ \\
\hline $\begin{array}{l}\text { 3-methyl-2-(2-oxoindolin-3-ylideneamino)butanoic acid } \\
\left(\mathrm{C}_{13} \mathrm{H}_{14} \mathrm{~N}_{2} \mathrm{O}_{3}\right) \mathrm{L}^{2} \mathrm{H}\end{array}$ & $\begin{array}{l}\text { Brownish } \\
\text { red }\end{array}$ & $\begin{array}{l}0.190 \mathrm{gm} \\
68.1 \%\end{array}$ & $104-105$ & $\begin{array}{c}63.28 \\
(63.40)\end{array}$ & $\begin{array}{c}5.68 \\
(5.73)\end{array}$ & $\begin{array}{c}11.31 \\
(11.38)\end{array}$ & $\begin{array}{c}239.33 \\
(246.26)\end{array}$ \\
\hline $\begin{array}{l}\text { 3-(1H-indol-3-yl)-2-(2-oxoindolin-3-ylideneamino) } \\
\text { propanoic acid }\left(\mathrm{C}_{19} \mathrm{H}_{15} \mathrm{~N}_{3} \mathrm{O}_{3}\right) \mathrm{L}^{3} \mathrm{H}\end{array}$ & $\begin{array}{l}\text { Light } \\
\text { brown }\end{array}$ & $\begin{array}{l}0.272 \mathrm{gm} \\
76.97 \%\end{array}$ & $128-130$ & $\begin{array}{c}68.55 \\
(68.46)\end{array}$ & $\begin{array}{c}4.46 \\
(4.54)\end{array}$ & $\begin{array}{c}12.58 \\
(12.61)\end{array}$ & $\begin{array}{c}338.65 \\
(333.34)\end{array}$ \\
\hline $\begin{array}{l}\text { 2-(5-chloro-2-oxoindolin-3-ylideneamino)propanoic } \\
\text { acid }\left(\mathrm{C}_{11} \mathrm{H}_{9} \mathrm{ClN}_{2} \mathrm{O}_{3}\right) \mathrm{L}^{4} \mathrm{H}\end{array}$ & $\begin{array}{l}\text { Light } \\
\text { yellow }\end{array}$ & $\begin{array}{l}0.150 \mathrm{gm} \\
70.7 \%\end{array}$ & 140 & $\begin{array}{c}52.17 \\
(52.29)\end{array}$ & $\begin{array}{c}3.51 \\
(3.59)\end{array}$ & $\begin{array}{c}11.19 \\
(11.09)\end{array}$ & $\begin{array}{c}243.68 \\
(252.65)\end{array}$ \\
\hline $\begin{array}{l}\text { 2-(5-chloro-2-oxoindolin-3-ylideneamino)-3-methyl-but } \\
\text { anoic acid }\left(\mathrm{C}_{13} \mathrm{H}_{13} \mathrm{ClN}_{2} \mathrm{O}_{3}\right) \mathrm{L}^{5} \mathrm{H}\end{array}$ & Yellow & $\begin{array}{l}0.140 \mathrm{gm} \\
67.0 \%\end{array}$ & $150-152$ & $\begin{array}{c}55.47 \\
(55.62)\end{array}$ & $\begin{array}{c}4.62 \\
(4.67)\end{array}$ & $\begin{array}{c}9.89 \\
(9.98)\end{array}$ & $\begin{array}{c}293.36 \\
(280.71)\end{array}$ \\
\hline $\begin{array}{l}\text { 2-(5-chloro-2-oxoindolin-3-ylideneamino)-3-(1 } \mathrm{H} \text {-indol- } \\
\text { 3-yl)propanoic acid }\left(\mathrm{C}_{19} \mathrm{H}_{14} \mathrm{ClN}_{3} \mathrm{O}_{3}\right) \mathrm{L}^{6} \mathrm{H}\end{array}$ & Brown & $\begin{array}{l}0.280 \mathrm{gm} \\
89.4 \%\end{array}$ & $149-150$ & $\begin{array}{c}61.98 \\
(62.05)\end{array}$ & $\begin{array}{c}3.82 \\
(3.84)\end{array}$ & $\begin{array}{c}11.46 \\
(11.43)\end{array}$ & $\begin{array}{c}372.69 \\
(367.79)\end{array}$ \\
\hline
\end{tabular}

Table 2. Analytical and physical data of the organotin (IV) complexes.

\begin{tabular}{|c|c|c|c|c|c|c|c|c|c|c|c|}
\hline \multirow{2}{*}{$\begin{array}{l}\text { S. } \\
\text { No }\end{array}$} & \multicolumn{2}{|c|}{ Reactants } & \multirow{2}{*}{$\begin{array}{l}\text { Molar } \\
\text { ratio }\end{array}$} & \multirow{2}{*}{$\begin{array}{l}\text { Products \& } \\
\text { Colour }\end{array}$} & \multirow{2}{*}{$\begin{array}{l}\text { M.P. } \\
{ }^{\circ} \mathrm{C}(\mathrm{d})\end{array}$} & \multirow{2}{*}{ Yield (g) } & \multicolumn{4}{|c|}{ Elemental Analysis } & \multirow{2}{*}{$\begin{array}{l}\text { Mol. Wt. } \\
\text { Found } \\
\text { (Calcd.) }\end{array}$} \\
\hline & Metal & Ligands & & & & & $\% \mathrm{Sn}$ & $\% \mathrm{C}$ & $\% \mathrm{H}$ & $\% \mathrm{~N}$ & \\
\hline 1 & $\begin{array}{c}\mathrm{Bu}_{2} \mathrm{SnO} \\
0.34 \mathrm{~g}\end{array}$ & $\begin{array}{c}\mathrm{C}_{11} \mathrm{H}_{10} \mathrm{~N}_{2} \mathrm{O}_{3} \\
0.59 \mathrm{~g}\end{array}$ & $1: 2$ & $\begin{array}{c}\mathrm{C}_{30} \mathrm{H}_{36} \mathrm{~N}_{4} \mathrm{O}_{6} \mathrm{Sn} \\
\text { Red }\end{array}$ & 174 & $\begin{array}{c}0.64 \mathrm{~g} \\
70.22 \%\end{array}$ & $\begin{array}{c}17.57 \\
(17.79)\end{array}$ & $\begin{array}{c}53.81 \\
(53.99)\end{array}$ & $\begin{array}{c}5.40 \\
(5.44)\end{array}$ & $\begin{array}{c}8.18 \\
(8.40)\end{array}$ & $\begin{array}{c}658.51 \\
(667.34)\end{array}$ \\
\hline 2 & $\begin{array}{c}\mathrm{Bu}_{2} \mathrm{SnO} \\
0.28 \mathrm{~g}\end{array}$ & $\begin{array}{c}\mathrm{C}_{13} \mathrm{H}_{14} \mathrm{~N}_{2} \mathrm{O}_{3} \\
0.55 \mathrm{~g}\end{array}$ & $1: 2$ & $\begin{array}{c}\mathrm{C}_{34} \mathrm{H}_{44} \mathrm{~N}_{4} \mathrm{O}_{6} \mathrm{Sn} \\
\text { Brown }\end{array}$ & 250 & $\begin{array}{c}0.66 \mathrm{~g} \\
81.11 \%\end{array}$ & $\begin{array}{c}16.56 \\
(16.41)\end{array}$ & $\begin{array}{c}56.36 \\
(56.45)\end{array}$ & $\begin{array}{c}6.18 \\
(6.13)\end{array}$ & $\begin{array}{c}7.83 \\
(7.74)\end{array}$ & $\begin{array}{c}732.92 \\
(723.45)\end{array}$ \\
\hline 3 & $\begin{array}{c}\mathrm{Bu}_{2} \mathrm{SnO} \\
0.25 \mathrm{~g}\end{array}$ & $\begin{array}{c}\mathrm{C}_{19} \mathrm{H}_{15} \mathrm{~N}_{3} \mathrm{O}_{3} \\
0.67 \mathrm{~g}\end{array}$ & $1: 2$ & $\begin{array}{c}\mathrm{C}_{46} \mathrm{H}_{46} \mathrm{~N}_{6} \mathrm{O}_{6} \mathrm{Sn} \\
\mathrm{Red}\end{array}$ & 140 & $\begin{array}{c}0.80 \mathrm{~g} \\
88.75 \%\end{array}$ & $\begin{array}{c}13.01 \\
(13.23)\end{array}$ & $\begin{array}{c}61.68 \\
(61.55)\end{array}$ & $\begin{array}{c}5.11 \\
(5.17)\end{array}$ & $\begin{array}{c}9.26 \\
(9.36)\end{array}$ & $\begin{array}{c}881.43 \\
(897.60)\end{array}$ \\
\hline 4 & $\begin{array}{c}\mathrm{Bu}_{2} \mathrm{SnO} \\
0.25 \mathrm{~g}\end{array}$ & $\begin{array}{c}\mathrm{C}_{11} \mathrm{H}_{9} \mathrm{ClN}_{2} \mathrm{O}_{3} \\
0.51 \mathrm{~g}\end{array}$ & $1: 2$ & $\begin{array}{c}\mathrm{C}_{30} \mathrm{H}_{34} \mathrm{Cl}_{2} \mathrm{~N}_{4} \mathrm{O}_{6} \mathrm{Sn} \\
\text { Dark Brown }\end{array}$ & 260 & $\begin{array}{c}0.56 \mathrm{~g} \\
75.68 \%\end{array}$ & $\begin{array}{c}16.25 \\
(16.12)\end{array}$ & $\begin{array}{l}48.76 \\
(48.94)\end{array}$ & $\begin{array}{c}4.60 \\
(4.65)\end{array}$ & $\begin{array}{c}7.49 \\
(7.61)\end{array}$ & $\begin{array}{c}747.77 \\
(736.23)\end{array}$ \\
\hline 5 & $\begin{array}{c}\mathrm{Bu}_{2} \mathrm{SnO} \\
0.24 \mathrm{~g}\end{array}$ & $\begin{array}{c}\mathrm{C}_{13} \mathrm{H}_{13} \mathrm{ClN}_{2} \mathrm{O}_{3} \\
0.54 \mathrm{~g}\end{array}$ & $1: 2$ & $\begin{array}{c}\mathrm{C}_{34} \mathrm{H}_{42} \mathrm{Cl}_{2} \mathrm{~N}_{4} \mathrm{O}_{6} \mathrm{Sn} \\
\text { Brown }\end{array}$ & 274 & $\begin{array}{c}0.57 \mathrm{~g} \\
74.63 \%\end{array}$ & $\begin{array}{c}14.78 \\
(14.98)\end{array}$ & $\begin{array}{c}51.43 \\
(51.54)\end{array}$ & $\begin{array}{c}5.27 \\
(5.34)\end{array}$ & $\begin{array}{c}6.94 \\
(7.07)\end{array}$ & $\begin{array}{r}784.50 \\
(792.34)\end{array}$ \\
\hline 6 & $\begin{array}{c}\mathrm{Bu}_{2} \mathrm{SnO} \\
0.21 \mathrm{~g}\end{array}$ & $\begin{array}{c}\mathrm{C}_{19} \mathrm{H}_{14} \mathrm{ClN}_{3} \mathrm{O}_{3} \\
0.61 \mathrm{~g}\end{array}$ & $1: 2$ & $\begin{array}{c}\mathrm{C}_{46} \mathrm{H}_{44} \mathrm{Cl}_{2} \mathrm{~N}_{6} \mathrm{O}_{6} \mathrm{Sn} \\
\text { Dark Brown }\end{array}$ & 172 & $\begin{array}{c}0.59 \mathrm{~g} \\
72.21 \%\end{array}$ & $\begin{array}{c}12.03 \\
(12.28)\end{array}$ & $\begin{array}{c}57.24 \\
(57.16)\end{array}$ & $\begin{array}{c}4.46 \\
(4.59)\end{array}$ & $\begin{array}{c}8.72 \\
(8.70)\end{array}$ & $\begin{array}{c}951.12 \\
(966.49)\end{array}$ \\
\hline
\end{tabular}

activity was determined by measuring the diameter of the zone (mm) showing complete inhibition with respect to control (DMSO).

\section{RESULTS AND DISCUSSION}

The Schiff base (HL) and metal complexes are subjected to elemental analysis. The results of elemental analysis $(\mathrm{C}, \mathrm{H}$ and $\mathrm{N}$ ) with molecular formula and the melting points are presented in experimental part. The results obtained are in good agreement with those calculated for suggested formula. New organotin (IV) complexes were synthesized by the reaction of dibutyltin (IV) oxide with Schiff bases have been carried out in 1:2 molar ratios using anhydrous benzene and absolute methanol in 3:1 ratio as solvent. These reactions proceed with the liberation of water, which were azeotropically removed. The scheme of the Organotin (IV) complexes preparation is given by Scheme 1.

The above reactions were found to be quite facile and could be completed in $3-4 \mathrm{~h}$ of stirring. All these com-

\section{$\mathrm{Bu}_{2} \mathrm{SnO}+2 \widehat{\mathrm{N} \mathrm{OH}} \underset{\text { methanol+benzene }}{\stackrel{\text { reflux 6-8 } \mathrm{h} .}{\longrightarrow}} \mathrm{Bu}_{2} \mathrm{Sn}(\widehat{\mathrm{NO}})_{2}+\mathrm{H}_{2} \mathrm{O}$ \\ where $\overparen{\mathrm{N}} \mathrm{OH}$ represents the donor system of the Schiff bases}

Scheme 1. The scheme of the Organotin (IV) complexes preparation.

plexes are intensively coloured and solids. They are soluble in common organic solvents, DMF and DMSO. The compounds were dissolved in DMF and molar conductance $10^{-3} \mathrm{M}$ of solution at $25^{\circ} \mathrm{C}$ was measured. The molar conductance valves of the complexes fall in the range 14.85 to $26.14 \Omega^{-1} \cdot \mathrm{cm}^{2} \cdot \mathrm{mol}^{-1}$ indicating that these compounds are non-electrolytes. The elemental analyses data (Table 1) agree with the proposed formulae for the ligands and also confirmed the $\mathrm{Bu}_{2} \mathrm{SnL}_{2}$ (Figure 2) composition of the diorganotin (IV) complexes.

\subsection{IR Spectra}

The IR spectra of the complexes were compared with those of the free ligands (Table 3) in order to determine 
Table 3. Important IR spectral data $\left(\mathrm{cm}^{-1}\right)$ of Schiff bases and their corresponding organotin (IV) complexes.

\begin{tabular}{|c|c|c|c|c|c|c|c|c|c|}
\hline Compounds & $v(\mathrm{OH})$ & $v\left(\mathrm{C}=\mathrm{N}^{-}\right)$ & $v(\mathrm{C}=\mathrm{O})$ & $v(\mathrm{COO})_{\text {asym }}$ & $v(\mathrm{COO})_{\mathrm{sym}}$ & $\Delta v$ & $v(\mathrm{Sn}-\mathrm{C})$ & $v(\mathrm{Sn} \leftarrow \mathrm{N})$ & $v(\mathrm{Sn}-\mathrm{O})$ \\
\hline $\mathrm{L}^{1} \mathrm{H}$ & $3105-2790$ br & $1635 \mathrm{~s}$ & $1730 \mathrm{~s}$ & - & - & - & & - & - \\
\hline $\mathrm{Bu}_{2} \mathrm{Sn}\left(\mathrm{L}^{1}\right)_{2}$ & - & $1622 \mathrm{~s}$ & $1728 \mathrm{~s}$ & $1590 \mathrm{~s}$ & $1320 \mathrm{~m}$ & 270 & $644 \mathrm{w}$ & $542 \mathrm{~s}$ & $425 \mathrm{~m}$ \\
\hline $\mathrm{L}^{2} \mathrm{H}$ & $3100-2795$ br & $1632 \mathrm{~s}$ & $1726 \mathrm{~s}$ & - & - & - & & - & - \\
\hline $\mathrm{Bu}_{2} \mathrm{Sn}\left(\mathrm{L}^{2}\right)_{2}$ & - & $1620 \mathrm{~s}$ & $1727 \mathrm{~s}$ & $1595 \mathrm{~s}$ & $1330 \mathrm{~m}$ & 265 & $625 \mathrm{w}$ & $545 \mathrm{w}$ & $422 \mathrm{w}$ \\
\hline $\mathrm{L}^{3} \mathrm{H}$ & $3108-2795$ br & $1630 \mathrm{~s}$ & $1725 \mathrm{~s}$ & - & - & - & & - & - \\
\hline $\mathrm{Bu}_{2} \mathrm{Sn}\left(\mathrm{L}^{3}\right)_{2}$ & - & $1615 \mathrm{~s}$ & $1724 \mathrm{~s}$ & 1585 vs & $1325 \mathrm{~s}$ & 260 & $635 \mathrm{w}$ & $540 \mathrm{~m}$ & $430 \mathrm{w}$ \\
\hline $\mathrm{L}^{4} \mathrm{H}$ & $3095-2790$ br & $1630 \mathrm{~s}$ & $1720 \mathrm{~s}$ & - & - & - & & - & - \\
\hline $\mathrm{Bu}_{2} \mathrm{Sn}\left(\mathrm{L}^{4}\right)_{2}$ & - & $1618 \mathrm{~s}$ & $1722 \mathrm{~s}$ & $1590 \mathrm{~s}$ & 1328 vs & 262 & $640 \mathrm{w}$ & $555 \mathrm{~m}$ & $428 w$ \\
\hline $\mathrm{L}^{5} \mathrm{H}$ & $3105-2810 \mathrm{br}$ & $1632 \mathrm{~s}$ & $1725 \mathrm{~s}$ & - & - & - & & - & - \\
\hline $\mathrm{Bu}_{2} \mathrm{Sn}\left(\mathrm{L}^{5}\right)_{2}$ & - & $1618 \mathrm{~s}$ & $1728 \mathrm{~s}$ & $1600 \mathrm{~s}$ & $1332 \mathrm{~m}$ & 268 & $628 \mathrm{w}$ & $540 \mathrm{w}$ & $425 \mathrm{~m}$ \\
\hline$L^{6} \mathrm{H}$ & $3110-2800 \mathrm{br}$ & $1640 \mathrm{~s}$ & $1728 \mathrm{~s}$ & - & - & - & & - & - \\
\hline $\mathrm{Bu}_{2} \mathrm{Sn}\left(\mathrm{L}^{6}\right)_{2}$ & - & $1625 \mathrm{~s}$ & $1726 \mathrm{~s}$ & $1588 \mathrm{~s}$ & $1316 \mathrm{~m}$ & 272 & $630 \mathrm{w}$ & $550 \mathrm{~s}$ & $435 \mathrm{w}$ \\
\hline
\end{tabular}

$\mathrm{br}=$ broad $; \mathrm{vs}=$ very sharp $\mathrm{v}=$ sharp $\mathrm{m}=$ medium $; \mathrm{w}=$ weak .<smiles></smiles>

Figure 2. Structure of organotin (IV) complexes.

the coordination sites that may be involved in chelation. The position and the intensities of these peaks are expected to be changed on chelation. New peaks and quasipeaks are also a guide to chelation. The IR spectra of all the ligands [27] show the absence of band at 3450 and $1750 \mathrm{~cm}^{-1}$ due to $v\left(\mathrm{NH}_{2}\right)$ group of amino acids and $v$ $(\mathrm{C}=\mathrm{O})$ of isatin. Instead, a new prominent band at $1635 \pm$ $5 \mathrm{~cm}^{-1}$ due to azomethine $v(\mathrm{C}=\mathrm{N})$ linkage appeared in all the ligands $[28,29]$ indicating that condensation between ketone moiety of isatin and that of amino group of amino acid has take place resulting into the formation of the desired ligands $\left(\mathrm{L}^{1} \mathrm{H}-\mathrm{L}^{6} \mathrm{H}\right)$. Moreover, on comparison of the IR spectra of the ligands with their organotin (IV) complexes showed a major shift to lower wave numbers by $12-20 \mathrm{~cm}^{-1}$ in azomethine $v(\mathrm{C}=\mathrm{N})$ at $1620 \pm 5 \mathrm{~cm}^{-1}$ suggesting the involvement of the azomethine nitrogen with the organotin (IV) ion [30,31]. The new bands ap- peared in the region of $545 \pm 10 \mathrm{~cm}^{-1}$ in the spectra of the complexes, are assigned to stretching frequencies of $v(\mathrm{Sn} \leftarrow \mathrm{N})[31]$ bond formations.

The spectra of the ligands contain a broad absorption band appeared in the region $3110-2790 \mathrm{~cm}^{-1}$ which is assigned to hydrogen bonded $v(\mathrm{OH})$. This band disappears on complexation, suggesting chelation of the oxygen to the tin atom [32]. The infrared spectra of complexes revealed that the $v_{\text {asym }}\left(\mathrm{COO}^{-}\right)$was shifted to a lower wave number compared to the parent ligands which signify that the coordination took place via the oxygen atom of the carboxylate anion. Complexes showed the $v_{\text {asym }}\left(\mathrm{COO}^{-}\right)$and $v_{\text {sym }}\left(\mathrm{COO}^{-}\right)$are in the range of 1600 1585 and $1330-1316 \mathrm{~cm}^{-1}$, respectively $[33,34]$.

Upon complexation, the structures of the ligands are altered, all alterations can be observed through the shift of the characteristic bands. The remarkable change is the disappearance of $v(\mathrm{OH})\left(3110-2790 \mathrm{~cm}^{-1}\right)$. This is attributable to $v_{\text {asym }}\left(\mathrm{COO}^{-}\right)$and $v_{\text {sym }}\left(\mathrm{COO}^{-}\right)$existing in the spectra of all the complexes, thus supporting the deportonation of carboxylic group and coordination of its carboxylic oxygen to the tin(IV) ion. The magnitude of $\Delta v=$ $\left[v_{\text {asym }}\left(\mathrm{COO}^{-}\right)-v_{\text {sym }}\left(\mathrm{COO}^{-}\right)\right]$for the complexes falls in the range of $272-260 \mathrm{~cm}^{-1}$, indicating the carboxyl group in all the complexes is bound in monodentate manner [35]. Moreover, for complexes $\Delta v$ below 200 $\mathrm{cm}^{-1}$ would be expected for bridging or chelating carboxylate, but greater than $200 \mathrm{~cm}^{-1}$ for the monodentate bonding carboxylate anions. Further evidence for the coordination to tin via oxygen atom was revealed by the presence of the $v(\mathrm{Sn}-\mathrm{O})$ [36] stretching bands in the spectra of complexes $(1-6)$ in the region of $422-435$ 
$\mathrm{cm}^{-1}$. New band appear in the complexes at $630 \pm 5 \mathrm{~cm}^{-1}$ is probably due to $v(\mathrm{Sn}-\mathrm{C})$ [37] stretching.

\subsection{Electronic Spectra}

The spectra of the ligands and their complexes were recorded in dry DMSO. The various bands observed were assigned to interligand and charge transfer of $n-\pi^{*}$ transition according to their energies and intensities. Electronic spectra of the complexes exhibit three bands in the region $200-235,250-345$ and $365-430 \mathrm{~nm}$, which may be due to the $\pi-\pi^{*}$ transition of benzenoid, $\pi-\pi^{*}$ transition of $\mathrm{COO}$ and $\pi-\pi^{*}$ transition of the $>\mathrm{C}=\mathrm{N}^{-}$ chromophore, respectively. Further, there was a sharp band observed in the $250 \pm 5 \mathrm{~nm}$ regions in the spectra of the complexes, which could be assigned as a charge transfer band. It has been reported that a metal is capable of forming $\mathrm{d} \pi$-p $\pi^{*}$ bonds with ligands containing nitrogen or oxygen as the donor atoms. Since tin atom has its $5 \mathrm{~d}$ orbitals completely vacant, L-M bonding can take place by the acceptance of a pair of electrons from nitrogen or oxygen atoms of the ligands.

\section{3. ${ }^{1} \mathrm{H}$ NMR Spectra}

All the protons were found as to be in their expected regions (Table 4). The conclusions drawn from these studies lend further support to the mode of bonding discussed in their IR spectra. In the spectra of organotin (IV) complexes, coordination of the ligands via azomethine nitrogen and carboxylate oxygen was established by the downfield shifting of these signals in the organotin (IV) complexes, because of the increased conjugation and coordination [38]. The number of protons calculated from the integration curves and those obtained from the values of the expected $\mathrm{CHN}$ analyses agree with each other. It was observed that DMSO had no coordinating effect either on the spectra of the ligands or on its metal complexes. In the proton magnetic resonance spectra of the ligands, give an $\mathrm{OH}$ proton signals at $\delta 11.25-11.50$ ppm (s) which is absent from the spectra of the corresponding lead complexes, showing thereby chelation of the ligand moiety through the deprotonated carboxylate oxygen. The ligands give a complex multiplet signal in the region $\delta 6.95-7.89 \mathrm{ppm}(\mathrm{m})$ for the aromatic protons and these remain almost at the same position in the spectra of the metal complexes. The appearance of signals due to NH protons at the same positions in the ligand and its complexes show the non-involvement of this group in coordination. The complexes, however, show additional signals at $\delta 0.72-1.90 \mathrm{ppm}$ owing to the protons of the

Table 4. ${ }^{1} \mathrm{H}$ NMR spectral data ${ }^{\mathrm{a}}$ of the ligands and their corresponding organotin (IV) complexes.

\begin{tabular}{|c|c|c|c|c|c|}
\hline \multirow{2}{*}{ Compounds } & \multicolumn{5}{|c|}{ Chemical Shift ( $\delta$ ppm) } \\
\hline & $\mathrm{COOH}$ & $\mathrm{N}-\mathrm{C} \underline{\mathrm{H}}-\mathrm{C}$ & $\mathrm{NH}$ & Aromatic & $\mathrm{Sn}-\mathrm{Bu}$ \\
\hline $\mathrm{L}^{1} \mathrm{H}$ & $\begin{array}{l}11.25 \\
(\mathrm{~s}, 1 \mathrm{H})\end{array}$ & $\begin{array}{c}4.72 \\
(\mathrm{q}, 1 \mathrm{H}, 8.4)\end{array}$ & $\begin{array}{c}8.34 \\
(\mathrm{~s}, 1 \mathrm{H})\end{array}$ & $\begin{array}{l}7.82(\mathrm{t}, \mathrm{H}-5,7.7), 7.21 \text { (dd, H-6, 7.4, 7.3), } \\
7.34 \text { (dd, H-7, 7.3, 7.4), } 7.64 \text { (t, H-8, 7.8) }\end{array}$ & - \\
\hline $\mathrm{Bu}_{2} \mathrm{Sn}\left(\mathrm{L}^{1}\right)_{2}$ & - & $\begin{array}{c}4.76 \\
(\mathrm{q}, 2 \mathrm{H}, 8.3)\end{array}$ & $\begin{array}{c}8.36 \\
(\mathrm{~s}, 2 \mathrm{H})\end{array}$ & $\begin{array}{l}7.80(\mathrm{t}, \mathrm{H}-5,7.7), 7.20(\mathrm{dd}, \mathrm{H}-6,7.4,7.3) \\
7.35(\mathrm{dd}, \mathrm{H}-7,7.3,7.4), 7.63(\mathrm{t}, \mathrm{H}-8,7.8)\end{array}$ & $\begin{array}{c}0.81(\mathrm{t}, 6 \mathrm{H}, 7.2), \\
1.32-1.82(\mathrm{~m}, 12 \mathrm{H})\end{array}$ \\
\hline $\mathrm{L}^{2} \mathrm{H}$ & $\begin{array}{l}11.32 \\
(\mathrm{~s}, 1 \mathrm{H})\end{array}$ & $\begin{array}{c}4.28 \\
(\mathrm{~d}, 1 \mathrm{H}, 6.9)\end{array}$ & $\begin{array}{c}8.47 \\
(\mathrm{~s}, 1 \mathrm{H})\end{array}$ & $\begin{array}{l}7.81(\mathrm{t}, \mathrm{H}-5,7.6), 7.18 \text { (dd, H-6, 7.3, 7.3), } \\
7.25(\mathrm{dd}, \mathrm{H}-7,7.3,7.2), 7.50(\mathrm{t}, \mathrm{H}-8,8.0)\end{array}$ & - \\
\hline $\mathrm{Bu}_{2} \mathrm{Sn}\left(\mathrm{L}^{2}\right)_{2}$ & - & $\begin{array}{c}4.30 \\
(\mathrm{~d}, 2 \mathrm{H}, 6.9)\end{array}$ & $\begin{array}{c}8.46 \\
(\mathrm{~s}, 2 \mathrm{H})\end{array}$ & $\begin{array}{l}7.80(\mathrm{t}, \mathrm{H}-5,7.6), 7.16 \text { (dd, H-6, 7.3, 7.4), } \\
7.25(\mathrm{dd}, \mathrm{H}-7,7.4,7.5), 7.48(\mathrm{t}, \mathrm{H}-8,8.0)\end{array}$ & $\begin{array}{c}0.85(\mathrm{t}, 6 \mathrm{H}, 7.4), \\
1.30-1.85(\mathrm{~m}, 12 \mathrm{H})\end{array}$ \\
\hline $\mathrm{L}^{3} \mathrm{H}$ & $\begin{array}{l}11.46 \\
(\mathrm{~s}, 1 \mathrm{H})\end{array}$ & $\begin{array}{c}4.39 \\
(\mathrm{t}, 1 \mathrm{H}, 8.3)\end{array}$ & $\begin{array}{c}8.09 \\
(\mathrm{~s}, 1 \mathrm{H})\end{array}$ & $\begin{array}{l}7.85 \text { (t, H-5, 7.6), } 7.18 \text { (dd, H-6, 7.5,2.4), } \\
7.34 \text { (dd, H-7, 2.4, 7.8), } 7.65(\mathrm{t}, \mathrm{H}-8,7.8)\end{array}$ & - \\
\hline $\mathrm{Bu}_{2} \mathrm{Sn}\left(\mathrm{L}^{3}\right)_{2}$ & - & $\begin{array}{c}4.38 \\
(\mathrm{t}, 2 \mathrm{H}, 8.3)\end{array}$ & $\begin{array}{l}8.12 \\
(\mathrm{~s}, 2 \mathrm{H})\end{array}$ & $\begin{array}{l}7.83(\mathrm{t}, \mathrm{H}-5,7.6), 7.17 \text { (dd, H-6, 7.5, 7.5), } \\
7.34 \text { (dd, H-7, 7.5, 7.6), } 7.64(\mathrm{t}, \mathrm{H}-8,7.8)\end{array}$ & $\begin{array}{c}0.76(\mathrm{t}, 6 \mathrm{H}, 7.1) \\
1.25-1.88(\mathrm{~m}, 12 \mathrm{H})\end{array}$ \\
\hline $\mathrm{L}^{4} \mathrm{H}$ & $\begin{array}{l}11.32 \\
(\mathrm{~s}, 1 \mathrm{H})\end{array}$ & $\begin{array}{c}4.14 \\
(\mathrm{q}, 1 \mathrm{H}, 8.8)\end{array}$ & $\begin{array}{c}7.98 \\
(\mathrm{~s}, 1 \mathrm{H})\end{array}$ & 7.76 (s, H-5), 7.45 (t, H-7, 7.9), 7.58 (t, H-8, 7.9) & - \\
\hline $\mathrm{Bu}_{2} \mathrm{Sn}\left(\mathrm{L}^{4}\right)_{2}$ & - & $\begin{array}{c}4.16 \\
(q, 2 \mathrm{H}, 8.7)\end{array}$ & $\begin{array}{l}7.96 \\
(\mathrm{~s}, 2 \mathrm{H})\end{array}$ & 7.75 (s, H-5), 7.43 (t, H-7, 7.6), 7.56 (t, H-8, 8.0) & $\begin{array}{c}0.80(\mathrm{t}, 6 \mathrm{H}, 7.0), \\
1.20-1.88(\mathrm{~m}, 12 \mathrm{H})\end{array}$ \\
\hline $\mathrm{L}^{5} \mathrm{H}$ & $\begin{array}{l}11.41 \\
(\mathrm{~s}, 1 \mathrm{H})\end{array}$ & $\begin{array}{c}4.08 \\
(\mathrm{~d}, 1 \mathrm{H}, 6.2)\end{array}$ & $\begin{array}{c}8.52 \\
(\mathrm{~s}, 1 \mathrm{H})\end{array}$ & 7.83 (s, H-5), 7.38 (t, H-7, 7.4), 7.66 (t, H-8, 8.1) & - \\
\hline $\mathrm{Bu}_{2} \mathrm{Sn}\left(\mathrm{L}^{5}\right)_{2}$ & - & $\begin{array}{c}4.11 \\
(\mathrm{~d}, 2 \mathrm{H}, 6.2)\end{array}$ & $\begin{array}{c}8.54 \\
(\mathrm{~s}, 2 \mathrm{H})\end{array}$ & 7.80 (s, H-5), 7.38 (t, H-7, 7.5), 7.64 (t, H-8, 8.0) & $\begin{array}{c}0.78(\mathrm{t}, 6 \mathrm{H}, 6.9) \\
1.30-1.78(\mathrm{~m}, 12 \mathrm{H})\end{array}$ \\
\hline $\mathrm{L}^{6} \mathrm{H}$ & $\begin{array}{c}11.50 \\
(\mathrm{~s}, 1 \mathrm{H})\end{array}$ & $\begin{array}{c}4.20 \\
(\mathrm{t}, 1 \mathrm{H}, 8.1)\end{array}$ & $\begin{array}{c}8.15 \\
(\mathrm{~s}, 1 \mathrm{H})\end{array}$ & 7.78 (s, H-5), 7.31 (t, H-7, 7.8), 7.15 (t, H-8, 8.0) & - \\
\hline $\mathrm{Bu}_{2} \mathrm{Sn}\left(\mathrm{L}^{6}\right)_{2}$ & - & $\begin{array}{c}4.15 \\
(\mathrm{t}, 2 \mathrm{H}, 8.1)\end{array}$ & $\begin{array}{c}8.14 \\
(\mathrm{~s}, 2 \mathrm{H})\end{array}$ & 7.77 (s, H-5), 7.30 (t, H-7, 7.8), 7.13 (t, H-8, 8.1) & $\begin{array}{c}0.80(\mathrm{t}, 6 \mathrm{H}, 6.8) \\
1.29-1.90(\mathrm{~m}, 12 \mathrm{H})\end{array}$ \\
\hline
\end{tabular}

${ }^{\mathrm{a}} \mathrm{Chemical}$ shift $(\delta)$ in ppm. ${ }^{\mathrm{n} J}\left({ }^{1} \mathrm{H}, \mathrm{H}^{1}\right)$, vales are given in $\mathrm{Hz}$ are listed in square brackets, respectively. Multiplicity is given as: $\mathrm{s}=$ singlet, $\mathrm{d}=$ doublet, $\mathrm{t}=$ triplet, $\mathrm{q}=$ quartet, $\mathrm{m}=$ complex pattern. 
butyl group. The $\mathrm{CH}_{3}$ protons of dibutyltin compounds are significant as a triplet at $0.78-82 \mathrm{ppm}$ with ${ }^{3} \mathrm{~J}_{\mathrm{HH}}=$ $7.4 \mathrm{~Hz}$, while $-\mathrm{CH}_{2}$-protons appear as a multiplet. The most important information obtained from ${ }^{1} \mathrm{H}$ NMR values in these compounds, demonstrates that diorganotion complexes show the coordination number greater than four, probably six, in non coordinating solvent.

\section{4. ${ }^{13} \mathrm{C}$ NMR Spectra}

The ${ }^{13} \mathrm{C}$ NMR spectral data for $\mathrm{L}^{1} \mathrm{H}, \mathrm{L}^{2} \mathrm{H}, \mathrm{L}{ }^{4} \mathrm{H}$ and its corresponding tin complexes have been recorded in dry DMSO (Table 5). The formations of the complexes were evident from the $\delta(\mathrm{COO})$ value in the ${ }^{13} \mathrm{C}$ NMR spectra. All the complexes exhibited a $\delta(\mathrm{COO})$ signal in the range of $172-178 \mathrm{ppm}$. The ${ }^{13} \mathrm{C}$ NMR spectra of complexes showed that the chemical shift of the $\delta(\mathrm{COO})$ signal in each complexes was shifted downfield compared to that of their parent ligands $(\sim \delta 175 \mathrm{ppm})$, indicating the participation of the carboxylate anion in the coordination to the tin atom. The occurrence of resonances in the range of $110-150 \mathrm{ppm}$ in the ${ }^{13} \mathrm{C} \mathrm{NMR}$ spectra of the complexes and ligands defined as benzene signals. The carbon of the butyl group is observed at $(\delta \sim$ $26.6,27.8,26.0,14.3 \mathrm{ppm})$ position comparable to other similar compounds. The $\mathrm{R}$ group attached to tin displays resonance for chemically equivalent carbon; however, the butyl compounds display three resonances. Coordination of the tin atom has been related to ${ }^{1} \mathrm{~J}\left({ }^{119} \mathrm{Sn}-{ }^{13} \mathrm{C}\right)$ coupling constants. The ${ }^{\mathrm{n}} \mathrm{J}\left({ }^{119} \mathrm{Sn}-{ }^{13} \mathrm{C}\right)$ coupling constant values $(\mathrm{n}=1,925 \mathrm{~Hz} ; \mathrm{n}=2,40.6 \mathrm{~Hz}$; and $\mathrm{n}=3,126.1$ $\mathrm{Hz}$ ) obtained for the synthesized complexes are indicative of hexa coordination of dibutyltin complexes. The carbons of alkyl groups attached to tin are observed at position comparable with other, similar compounds [39, 40].

\section{5. ${ }^{119}$ Sn NMR Spectra}

The value of $\delta\left({ }^{119} \mathrm{Sn}\right)$ define the coordination number of the central tin atom. The results are listed in Table 5. All the complexes, ${ }^{119} \mathrm{Sn}$ NMR spectra show only a sharp singlet indicating the formation of a single species. For diorganotin(IV) complexes, the $\delta\left({ }^{119} \mathrm{Sn}\right)$ value for fourcoordinated complexes fall in the range between $\delta+200$ to $\delta-60 \mathrm{ppm}$; for five-coordinated complexes fall in the range between $\delta-90$ to $\delta-190$ ppm and for six-coordinated complexes fall in the range between $\delta-210$ to $\delta$ -400 ppm. Complexes 1 - 6 derivatives of dibutyltin(IV) exhibited $\delta\left({ }^{119} \mathrm{Sn}\right)$ values at $\sim \delta-360 \mathrm{ppm}$ which lie in the range of $\delta-210$ to $\delta-400 \mathrm{ppm}$, hence, indicating that the tin atom in all the complexes have six-coordinated and have a distorted octahedral geometry [41-43].

On the basis of the above mentioned different spectral studies, it is suggested that the bonding through the azomethine nitrogen and carboxylate oxygen atoms to the tin atom. Finally, distorted octahedral geometries around the tin atom have been proposed as shown in Figure 2.

\subsection{Molecular Modeling and Analysis}

In view of the hexa-coordination of the present tin complexes, $\left[\mathrm{Bu}_{2} \mathrm{Sn}\left(\mathrm{L}^{1}\right)_{2}\right]$, the molecular modeling of the compound as a representation, is based on its octahedral structure and all the 237 measurements are obtained (bond angles, 155 in numbers and the bond lengths, 82 in numbers). In most of the cases, the actual bond angles and lengths are close to the optimal values, and thus the proposed structure of the compound is acceptable (Figure 3). In compound $\left[\mathrm{Bu}_{2} \mathrm{Sn}\left(\mathrm{L}^{1}\right)_{2}\right]$, the $\mathrm{Sn}$ atom is 2.01 and $3.9 \AA$ away from the oxygen's of the carboxylic group. The two long Sn-O bond being Trans to each other. The C-O bonds are nearly (1.39 and $1.21 \AA)$. The two butyl groups are equidistant from $\mathrm{Sn}(2.10 \AA)$ and complete the

Table 5. ${ }^{13} \mathrm{C}$ and ${ }^{119} \mathrm{Sn}$ NMR spectral data ${ }^{\mathrm{a}}$ of the ligands and their corresponding organotin (IV) complexes.

\begin{tabular}{|c|c|c|c|c|c|c|c|c|}
\hline \multirow{2}{*}{ Compounds } & \multicolumn{8}{|c|}{ Chemical Shift in ( $\delta$ ppm) } \\
\hline & ${ }^{119} \mathrm{Sn}$ & $\mathrm{C}-1 / \mathrm{C}-7$ & $\mathrm{C}-2 / \mathrm{C}-8$ & C-3/C-9 & C-4/C-10 & C-5/C-11 & C-6/C-12 & $\mathrm{Sn}-\mathrm{CH}_{2} \mathrm{CH}_{2} \mathrm{CH}_{2} \mathrm{CH}_{3}$ \\
\hline $\mathrm{L}^{1} \mathrm{H}$ & - & $\begin{array}{l}172.6 \\
133.8\end{array}$ & $\begin{array}{c}63.5 \\
110.9\end{array}$ & $\begin{array}{l}155.8 \\
148.5\end{array}$ & $\begin{array}{l}159.9 \\
121.3\end{array}$ & $\begin{array}{c}130.4 \\
20.2\end{array}$ & $\begin{array}{c}129.5 \\
-\end{array}$ & - \\
\hline $\mathrm{Bu}_{2} \mathrm{Sn}\left(\mathrm{L}^{1}\right)_{2}$ & -360 & $\begin{array}{l}183.3 \\
134.1\end{array}$ & $\begin{array}{c}64.8 \\
111.3\end{array}$ & $\begin{array}{l}160.2 \\
148.3\end{array}$ & $\begin{array}{l}153.4 \\
120.6\end{array}$ & $\begin{array}{c}130.8 \\
20.7\end{array}$ & $\begin{array}{c}129.4 \\
-\end{array}$ & $\begin{array}{c}27.2(\mathrm{C}-\alpha, 928 \mathrm{~Hz}), 28.4(\mathrm{C}-\beta, 40.2 \mathrm{~Hz}), \\
26.9(\mathrm{C}-\gamma, 125.8 \mathrm{~Hz}), 13.7(\mathrm{C}-\delta)\end{array}$ \\
\hline $\mathrm{L}^{2} \mathrm{H}$ & - & $\begin{array}{l}175.7 \\
140.6\end{array}$ & $\begin{array}{c}68.3 \\
120.5\end{array}$ & $\begin{array}{l}161.3 \\
150.8\end{array}$ & $\begin{array}{l}160.5 \\
121.5\end{array}$ & $\begin{array}{c}131.5 \\
31.4\end{array}$ & $\begin{array}{c}123.1 \\
19.2\end{array}$ & - \\
\hline $\mathrm{Bu}_{2} \mathrm{Sn}\left(\mathrm{L}^{2}\right)_{2}$ & -358 & $\begin{array}{l}182.7 \\
141.3\end{array}$ & $\begin{array}{c}71.1 \\
120.6\end{array}$ & $\begin{array}{l}161.5 \\
150.0\end{array}$ & $\begin{array}{l}151.5 \\
121.9\end{array}$ & $\begin{array}{c}132.1 \\
31.2\end{array}$ & $\begin{array}{c}123.1 \\
20.1\end{array}$ & $\begin{array}{c}27.5(\mathrm{C}-\alpha, 928 \mathrm{~Hz}), 28.9(\mathrm{C}-\beta, 39.9 \mathrm{~Hz}), \\
26.3(\mathrm{C}-\gamma, 126.2 \mathrm{~Hz}), 14.1(\mathrm{C}-\delta)\end{array}$ \\
\hline $\mathrm{L}^{4} \mathrm{H}$ & - & $\begin{array}{l}177.5 \\
134.2\end{array}$ & $\begin{array}{c}65.1 \\
115.3\end{array}$ & $\begin{array}{l}160.2 \\
145.7\end{array}$ & $\begin{array}{l}162.4 \\
121.0\end{array}$ & $\begin{array}{c}131.2 \\
20.2\end{array}$ & $\begin{array}{c}129.7 \\
-\end{array}$ & - \\
\hline $\mathrm{Bu}_{2} \mathrm{Sn}\left(\mathrm{L}^{3}\right)_{2}$ & -355 & $\begin{array}{l}184.1 \\
138.5\end{array}$ & $\begin{array}{c}65.7 \\
116.5\end{array}$ & $\begin{array}{l}160.1 \\
145.2\end{array}$ & $\begin{array}{l}154.6 \\
120.8\end{array}$ & $\begin{array}{c}131.5 \\
20.8\end{array}$ & $\begin{array}{c}129.4 \\
-\end{array}$ & $\begin{array}{c}28.4(\mathrm{C}-\alpha, 925 \mathrm{~Hz}), 29.2(\mathrm{C}-\beta, 40.6 \mathrm{~Hz}) \\
27.7(\mathrm{C}-\gamma, 126.1 \mathrm{~Hz}), 14.6(\mathrm{C}-\delta)\end{array}$ \\
\hline
\end{tabular}

${ }^{\mathrm{a}}$ Chemical shift $(\delta)$ in ppm. ${ }^{\mathrm{n}} \mathrm{J}\left({ }^{119} \mathrm{Sn}-{ }^{13} \mathrm{C}\right)$, vales are given in $\mathrm{Hz}$ are listed in square brackets. 


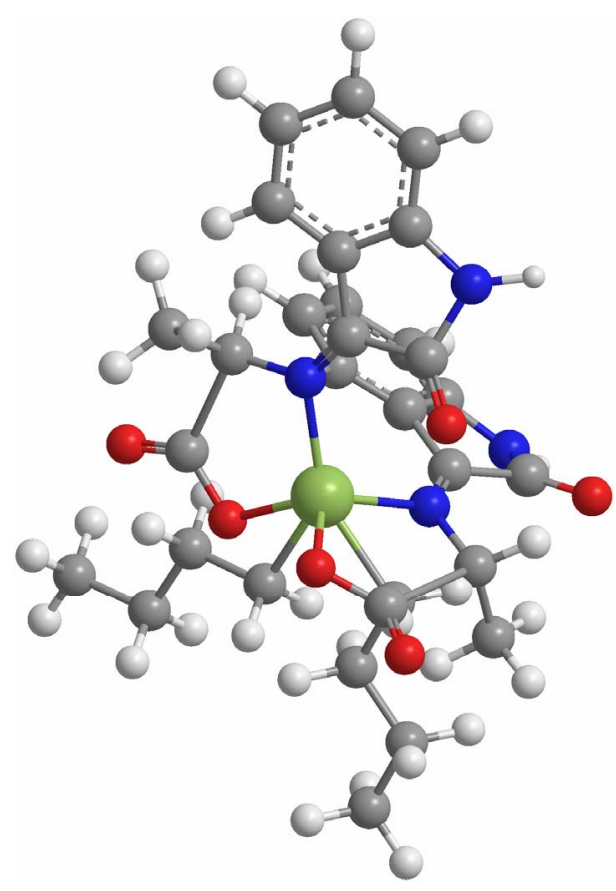

Figure 3. 3D structure of the $\left[\mathrm{Bu}_{2} \mathrm{Sn}\left(\mathrm{L}^{1}\right)_{2}\right]$ complexes.

coordination sphere of $\mathrm{Sn}$. The $\mathrm{Bu}(\mathrm{C})-\mathrm{Sn}-(\mathrm{C}) \mathrm{Bu}$ angles are $162.1^{\circ}$. The O-Sn-O and N-Sn-N angle are 109.5 and is $110.5^{\circ}$, respectively for both the carboxylic ligands.

\subsection{Antimicrobial Results}

In vitro antibacterial activity of the ligands and their corresponding organotin complexes was tested against Gram-positive and Gram-negative (Enterobacter aerogenes and Bacillus cereus) bacteria. The agar well-diffusion method was used in these assays and each experimental was performed in triplicate. The zone of inhibittion value represents the mean value of three readings, which are shown in Table 6. The results show that all compounds exhibit antibacterial activity and in many case, the organotin complexes are more potent in their inhibition properties than the free ligands. This can be explained in terms of the greater lipid solubility and cellular penetration of the complexes [44]. It is clear that the coordination enhances the antibacterial activity and clearly indicates that the newly synthesized complexes in the present studies are more active against Gram-positive than Gram-negative bacteria. The preliminary results achieved have led us to conclude that these types of complexes should be studied in detail for their applications in diverse areas.

The screening data of a particular ligand and its metal complexes show that the former has greater activity than the latter from the biochemical point of view. On comparing the results in general, it may be concluded that the
Table 6. Antibacterial and antifungal activity of ligands and their organotin (IV) complexes.

\begin{tabular}{ccccccc}
\hline & \multicolumn{5}{c}{ Zone of inhibition $(\mathrm{mm})^{*}$} \\
\cline { 2 - 7 } Compounds & \multicolumn{3}{c}{$\begin{array}{c}\text { Bacillus cereus } \\
(\text { MTCC } 0430)\end{array}$} & \multicolumn{3}{c}{$\begin{array}{c}\text { Enterobacter aerogenes } \\
\text { MTCC 2824 }\end{array}$} \\
\cline { 2 - 7 } & $25 \mu \mathrm{g}$ & $50 \mu \mathrm{g}$ & $100 \mu \mathrm{g}$ & $25 \mu \mathrm{g}$ & $50 \mu \mathrm{g}$ & $100 \mu \mathrm{g}$ \\
\hline $\mathrm{L}^{1}$ & 4.5 & 11.9 & 14.6 & 3.6 & 7.5 & 11.7 \\
$\mathrm{Bu}_{2} \mathrm{Sn}\left(\mathrm{L}^{1}\right)_{2}$ & 4.4 & 15.6 & 19.7 & 4.8 & 10.1 & 15.9 \\
$\mathrm{~L}^{2}$ & 5.5 & 12.3 & 15.5 & 5.55 & 10.2 & 14.5 \\
$\mathrm{Bu}_{2} \mathrm{Sn}\left(\mathrm{L}^{2}\right)_{2}$ & 6.9 & 16.5 & 20.2 & 7.2 & 13.6 & 17.8 \\
$\mathrm{~L}^{3}$ & 7.2 & 9.5 & 15.0 & 5.66 & 8.28 & 15.0 \\
$\mathrm{Bu}_{2} \mathrm{Sn}\left(\mathrm{L}^{3}\right)_{2}$ & 8.8 & 12.6 & 18.8 & 7.5 & 11.3 & 16.9 \\
\hline
\end{tabular}

${ }^{*}$ The zone of inhibition was measured with respect to control. DMSO (Dimethyl sulfo-oxide was taken as control and as well as solvent).

organotin (IV) complexes have greater inhibiting power than the free ligands against all the microbes. Although it is difficult to make out an exact structure-activity relationship between the antimicrobial activity and the structure of these complexes, it can possibly be concluded that the chelation as well as the addition of a substrate enhance the activity of the complexes. The variation in the toxicity of different antibacterial agents against various organisms depends on either the impermeability of the cell or differences in site of action or ability to cause mutations in the microorganism. Though the results suggest that the ligands have a remarkable toxic property, their complexes of tin inhibit the growth of microorganisms to a greater extent. This is in accordance with earlier reports [45]. Further, the greater activity of the complexes can also be explained on the basis of their higher solubility of the particles.

\section{CONCLUSION}

The newly synthesized Schiff bases act as bidntate ligands coordinating to metal ion through azomethine nitrogen, and carboxylate oxygen atom. Distorted octahedral geometries have been proposed for diorganotin (IV) complexes with the help of different spectral studies like IR, UV, ${ }^{1} \mathrm{H},{ }^{13} \mathrm{C}$ and ${ }^{119} \mathrm{Sn}$ NMR. The Schiff bases and their metal complexes were found to be active against some of the antibacterial and antifungal species. The activity is significantly increased on coordination.

\section{ACKNOWLEDGEMENTS}

The authors are thankful to the Dean, FET and Prof. K Singh, Head, department of science and humanities, FET, Mody Institute of Technology and Science, Deemed University, Lakshmangarh, for providing 
necessary research facilities in the department.

\section{REFERENCES}

[1] Li, C., Kanehisa, N., Miyagi, Y., Nakao, Y., Takamizawa, S., Mori, W. and Kai, Y. (1997) Syntheses, structures, and properties of the dinuclear copper(II) and nickel(II) complexes bridged by an alkoxide and a pyridazine or a phthalazine. Bulletin of the Chemical Society of Japan, 70, 2429-2436. doi:10.1246/bcsj.70.2429

[2] Ibrahim, E.S., Sallam, S.A., Orabi, A.S., El-Shetary, B.A. and Lentz, A. (1998) Schiff bases of acetone derivatives: Spectroscopic properties and physical constants. Monatshefte fur Chemie, 129, 159-171. doi:10.1007/PL00010152

[3] Campos, A., Anacona, J.R. and Campos, M.M. (1999) Synthesis and IR study of a Zn(II) complex containing a tetradentate macrocyclic Schiff base Ligand antifungal properties. Main Group Metal Chemistry, 22, 283-288. doi:10.1515/MGMC.1999.22.5.283

[4] Sengupta, S.K., Pandey, O.P., Rai, A. and Sinha, A. (2006) Synthesis, spectroscopic, thermal and antifungal studies on lanthanum(III) and praseodymium(III) derivatives of 1,1-diacetylferrocenyl hydrazones. Spectrochimica Acta A, 65, 139-142. doi:10.1016/j.saa.2005.09.037

[5] Qi, G.-F., Yang, Z.-Y and Wang, B.-D. (2007) Synthesis, characterization and DNA-binding properties of zinc(II) and nickel(II) Schiff base complexes. Transition Metal Chemistry, 32, 233-239. doi:10.1007/s11243-006-0160-8

[6] Singh, V. P. and Katiyar, A. (2008) Synthesis, spectral characterization and antimicrobial activity of some transition metal(II) complexes with acetone p-amino acetophenone benzoylhydrazone. Pesticide Biochemistry and Physiology, 92, 8-14. doi:10.1016/j.pestbp.2008.04.003

[7] Cozzi, P. G. (2004) Metal-Salen Schiff base complexes in catalysis: Practical aspects. Chemical Society Reviews, 33, 410-421. doi:10.1039/b307853c

[8] Iqbal, A., Siddiqui, H.L., Ashraf, C.M., Bukhar, M.H. and Akram, C.M. (2007) Synthesis, spectroscopic and cytotoxic studies of biologically active new Schiff Bases derived from $p$-nitrobenzaldehyde. Chemical and Pharmaceutical Bulletin, 55, 1070-1072. doi:10.1248/cpb.55.1070

[9] Offiong, O.E. and Martelli, S. (1997) Stereochemistry and antitumour activity of platinum metal complexes of 2-acetylpyridine thiosemicarbazones. Transition Metal Chemistry, 22, 263-269. doi:10.1023/A:1018416624951

[10] Maurya, R.C., Rajput, S. and Martin, H. (2006) Metal chelates as oral potential insulin adjuvants: Studies on some oxovanadium(IV) chelates involving biomimetic ono-donor sugars. Medicinal Chemistry Research, 15, 8283.

[11] Singh, H.L. and Varshney, A.K. (2006) Synthetic, structural, and biochemical studies of organotin (IV) with schiff bases having nitrogen and sulphur donor ligands. Bioinorganic Chemistry and Applications, 2006, 1-7. doi:10.1155/BCA/2006/23245

[12] Singh, H.L., Sharma, M. and Varshney, A.K. (2000) Studies on coordination compounds of organotin (IV) with
Schiff bases of amino acids. Synthesis and Reactivity in Inorganic and Metal-Organic Chemistry, 30, 445-456.

[13] Siddiqi, H.L., Iqbal, A., Ahmad, S. and Weaver, W. (2006) Synthesis and spectroscopic studies of New Schiff bases. Molecules, 11, 206-211. doi:10.3390/11020206

[14] Kim, S.-H., Gwon, S.-Y., Burkinshaw, S. M. and Son, Y.-A. (2010) The synthesis and proton-induced spectral switching of a novel azine dye and its boron complex. Dyes and Pigments, 87, 268-271. doi:10.1016/j.dyepig.2010.04.006

[15] Kumbhar, A.S., Padhye, S.B., West, D.X. and Liberta, A.E. (1991) Electrochemical studies of copper(II) 2-acetylpyridine ${ }^{4} \mathrm{~N}$-dialkylthiosemicarbazones. Relation to their spectral, magnetic, and biological properties. Transition Metal Chemistry, 16, 276-279. doi:10.1007/BF01032852

[16] Gielen, M. (2002) Review: Organotin compounds and their therapeutic potential. Applied Organometallic Chemistry, 16, 481-494. doi:10.1002/aoc.331

[17] Gielen, M., Biesemans, M. and Willem, R. (2005) Organotin compounds: From kinetics to stereochemistry and antitumour activities Applied Organometallic Chemistry, 19, 440-450. doi:10.1002/aoc.771

[18] Valent, A., Melník, M., Hudecová, D., Dudová, B., Kivekäs, R. and Sundberg, M.R. (2002) Copper(II) salicylideneglycinate complexes as potential antimicrobial agents. Inorganica Chimica Acta, 340, 15-20. doi:10.1016/S0020-1693(02)01062-9

[19] Nath, M., Singh, H., Eng, G. and Song, X. (2011) Interaction of organotin(IV) moieties with nucleic acid constituent: Synthesis, structural characterization and antiinflammatory activity of tri-i-propyltin(IV) and diorganotin(IV) derivatives of guanosine. Inorganic Chemistry Communications, 14, 1381-1385. doi:10.1016/j.inoche.2011.05.027

[20] Pellerito, C., Nagy, L., Pellerito, L. and Szorcsik, A.C. (2006) Biological activity studies on organotin(IV $)^{n+}$ complexes and parent compounds. Journal of Organometallic Chemistry, 691, 1733-1747.

doi:10.1016/j.jorganchem.2005.12.025

[21] Ahmad, M. S., Hussain, M., Hanif, M., Ali, S. and Mirza, B. (2007) Synthesis, chemical characterization and biological screening for cytotoxicity and antitumor activity of organotin (IV) derivatives of 3,4-methylenedioxy 6nitrophenylpropenoic acid. Molecules, 12, 2348-2363. doi: $10.3390 / 12102348$

[22] Saxena, A. and Tandon, J. P. (1983) Antitumor activity of some diorganotin and tin(IV) complexes of Schiff bases. Cancer Letters, 19, 73-76. doi:10.1016/0304-3835(83)90138-6

[23] Baul, T.S.B., Paul, A., Pellerito, L., Scopelliti, M., Singh, P., Verma, P., Duthie, A., De Vos, D. and Tiekink, E.R.T. (2011) Dibutyltin(IV) complexes containing arylazobenzoate ligands: Chemistry, in vitro cytotoxic effects on human tumor cell lines and mode of interaction with some enzymes. Investigational New Drugs, 29, 285-299. doi:10.1007/s10637-009-9360-3

[24] Sadiq-ur-Rehman, Shahid, K., Ali, S., Bhatti, M. H. and Parvez, M. (2005) Organotin esterification of (E)-3-(3- 
fluoro-phenyl)-2-(4-chlorophenyl)-2-propenoic acid: Synthesis, spectroscopic characterization and in vitro biological activities. Crystal structure of $\left[\mathrm{Ph}_{3} \mathrm{Sn}(\mathrm{OC}(\mathrm{O}) \mathrm{C}\right.$ $\left.\left.\left(4-\mathrm{ClC}_{6} \mathrm{H}_{4}\right)=\mathrm{CH}\left(3-\mathrm{FC}_{6} \mathrm{H}_{4}\right)\right)\right]$. Journal of Organometallic Chemistry, 690, 1396-1408. doi:10.1016/j.jorganchem.2004.12.004

[25] Perrin, D.D., Armarego, W.L.F. and Perrin, D.L. (1998) Purification of laborartory chemicals. 3rd Edition, Pergamon, London.

[26] Singh, H.L., Singh, J.B. and Sharma, K.P. (2012) Synthetic, structural, and antimicrobial studies of organotin (IV) complexes of semicarbazone, thiosemicarbazone derived from 4-hydroxy-3-methoxybenzaldehyde. Research on Chemical Intermediates, 38, 53-65. doi:10.1007/s11164-011-0325-8

[27] Ran, X., Wang, L., Cao, D., Lin, Y. and Hao, J. (2010) Synthesis, characterization and in vitro biological activity of cobalt(II), copper(II) and zinc(II) Schiff base complexes derived from salicylaldehyde and D,L-selenomethionine. Applied Organometallic Chemistry, 25, 9-15. doi:10.1002/aoc. 1680

[28] Singh, K., Kumar, Y. and Pundir, R.K. (2010) Synthesis and Characterization of biologically active organosilicon (IV) complexes with schiff bases derived from o-aminothiophenol. Synthesis and Reactivity in Inorganic and Metal-Organic Chemistry, 40, 836-842.

[29] Nath, M., Saini, P.K. and Kumar, A. (2010) New di- and triorganotin(IV) complexes of tripodal Schiff base ligand containing three imidazole arms: Synthesis, structural characterization, anti-inflammatory activity and thermal studies. Journal of Organometallic Chemistry, 695, 13531362. doi:10.1016/i.jorganchem.2010.02.009

[30] Ferrero, J.R. (1971) Low-frequency vibrations of inorganic and coordination compounds, John Wiley \& Sons, New York.

[31] Singh, H.L. and Varshney, A.K. (2001) Synthesis and characterization of coordination compounds of organotin (IV) with nitrogen and sulphur donor ligands. Applied Organometallic Chemistry, 15, 762-768. doi:10.1002/aoc. 234

[32] Singh, H.L. (2010) Synthesis and characterization of tin (II) complexes of fluorinated Schiff bases derived from amino acids. Spectrochimica Acta Part A, 76, 253-258. doi:10.1016/j.saa.2010.03.029

[33] Sandhu, G.K. and Verma, S.P. (1987) Triorganotin(IV) derivatives of five membered heterocyclic 2-carboxylic acids. Polyhedron, 6, 587-591. doi:10.1016/S0277-5387(00)81029-3

[34] Szorcsik, A., Nagy, L., Sletten, J., Szalontai, G., Kamu, E., Fiore, T., Pellerito, L. and Kálmán, E. (2004) Preparation and structural studies on dibutyltin(IV) complexes with pyridine mono- and dicarboxylic acids. Journal of Or- ganometallic Chemistry, 689, 1145-1154. doi:10.1016/j.jorganchem.2003.11.040

[35] Ho, B.Y.K. and Zuckerman, J.J. (1973) Trialkyltin derivatives of amino acids and dipeptides. Inorganic Chemistry, 12, 1552-1561. doi:10.1021/ic50125a016

[36] Sedaghat, T. and Jalilian, F. (2009) New adducts of diorganotin(IV) Chlorides with a new multifunctional Schiff base ligand: Synthesis and spectral properties. Journal of Iranian Chemical Society Synthesis, 6, 271-276.

[37] Singh, H.L. and Varshney, A.K. (1999) Synthesis and spectral studies of organotin(IV) complexes with bifunctional tetradentate Schiff bases. Main Group Metal Chemistry, 22, 529-532. doi:10.1515/MGMC.1999.22.9.529

[38] Pasto, D.J. (1969) Organic structure determination, Prentice Hall, London.

[39] Nath, M. and Yadav, R. (1998) Studies of organotin(IV) derivatives of DL-methionine and L-asparagine. Bulletin of the Chemical Society of Japan, 71, 1355-1362. doi:10.1246/bcsj.71.1355

[40] Joshi, A., Verma, S., Gaur, R. B. and Sharma, R. R. (2005) Di-n-butyltin(IV) Complexes Derived from Heterocyclic $\beta$-diketones and N-phthaloyl amino acids: Preparation, biological evaluation, structural elucidation based upon spectral [IR, NMR $\left({ }^{1} \mathrm{H},{ }^{13} \mathrm{C},{ }^{19} \mathrm{~F}\right.$ and $\left.{ }^{119} \mathrm{Sn}\right)$ ] studies. Bioinorganic Chemistry and Applications, 3, 201-215. doi:10.1155/BCA.2005.201

[41] Holeček, J., Nádvorník, M., Handlíř, K. and Lyčka, A. (1986) ${ }^{13} \mathrm{C}$ and ${ }^{119} \mathrm{Sn}$ NMR spectra of Di-n-butyltin(IV) compounds. Journal of Organometallic Chemistry, 315, 299-308. doi:10.1016/0022-328X(86)80450-8

[42] Jain, V. K., Mason, J., Saraswat, B.S. and Mehrotra, R.C. $(1985){ }^{15} \mathrm{~N},{ }^{13} \mathrm{C}$ and ${ }^{119} \mathrm{Sn}$ NMR and other spectroscopic studies of 8-quinolinol, its $O$ - and $N$-methyl derivatives, and chelate di- and tri-organotin(IV) complexes. Polyhedron, 4, 2089-2096. doi:10.1016/S0277-5387(00)86741-8

[43] Pettinari, C., Pellei, M., Miliani, M., Cingolani, A., Cassetta, A., Barba, L., Pifferi, A. and Rivarola, E. (1998) Tin(IV) and organotin(IV) complexes containing mono or bidentate N-donor ligands: III. ${ }^{1} 1$-methylimidazole derivatives: synthesis, spectroscopic and structural characterization. Journal of Organometallic Chemistry, 553, 345-369. doi:10.1016/S0022-328X(97)00606-2

[44] Chaturvedi, K.K. and Goyal, M. (1984) Antibacterial studies of 7-( $\alpha$-substituted sulphonamido)methyl- and 7-( $\alpha$-substituted sulphonamido)phenyl-8-hydroxyquinolines. Journal of the Indian Chemical Society, 61, 175176.

[45] Singh, H.L., Khungar, B., Tripaati, U.D. and Varshney, A.K. (2001) Spectral and antimicrobial studies of organotin(IV) complexes of bidentate schiff bases having nitrogen and sulphur donor systems. Main Group Metal Chemistry, 24, 5-12. doi:10.1515/MGMC.2001.24.1.5 